\title{
Desain dan Analisis Inverter Tiga Fasa Menggunakan Metode SPWM
}

\author{
Asnil \\ Teknik ELektro-Fakultas Teknik \\ Universitas Negeri Padang \\ Padang, Indonesia \\ asnil81@ft.unp.ac.id
}

\author{
Krismadinata \\ Teknik ELektro-Fakultas Teknik \\ Universitas Negeri Padang \\ Padang, Indonesia \\ krisma@ft.unp.ac.id
}

\author{
Irma Husnaini \\ Teknik ELektro-Fakultas Teknik \\ Universitas Negeri Padang \\ Padang, Indonesia \\ irma_hnni@ft.unp.ac.id
}

\begin{abstract}
Abstrak - Makalah ini membahas mengenai penerapan metode Sinusoidal Pulse Width Modulation (SPWM) dan filter pasif LC jenis low pass pada inverter tiga fasa sebagai upaya untuk mengurangi distorsi (harmonik) gelombang keluaran inverter. Dari simulasi menggunkan metode SPWM didapatkan nilai THD tegangan fasa keluaran inverter sebesar $68,72 \%$, tegangan fasa-fasa $68,71 \%$ dan arus $0,92 \%$. Gelombang tegangan keluaran inverter belum sinusoidal dan masih terdistorsi sedangkan gelombang arus sudah berbentuk sinusoidal. Untuk memperbaiki gelombang tegangan agar sinusoidal maka dipakai filter pasif LC. Setelah dipasang filter LC, bentuk gelombang keluaran inverter baik tegangan maupun arus sudah berbentuk sinusoidal. Sedangkan nilai THD tegangan dan arus juga terjadi pengurangan. Nilai THD gelombang keluaran inverter setelah dipasang filter untuk tegangan fasa menjadi $0,21 \%$, tegangan fasa-fasa menjadi $0,29 \%$ dan arus menjadi 0,15\%. Dengan demikian, penerapan metode SPWM dan filter pasif LC dapat menurunkan nilai TDH gelombang keluaran inverter dengan baik serta menjadikan gelombang keluaran sinusoidal.
\end{abstract}

Kata Kunci-Inverter, SPWM, Total Harmonik Distortion (THD).

\section{Pendahuluan}

Defisit energi listrik di Indonesia memang menjadi masalah klasik namun sampai sekarang masih belum terselesaikan. Setiap tahun, permintaan kebutuhan energi listrik selalu meningkat sedangkan pertumbuhan pasokan energi listrik selalu tertinggal dari peningkatan kebutuhan terutama pada daerah-daerah padat penduduk. Jika permasalahan ini masih berlanjut, bisa diperkirakan pada beberapa tahun kedepan akan terjadi ancaman krisis listrik total di Indonesia. Penggunaan energi terbarukan seperti tenaga air, angin, matahari, bioenergi, gelombang laut dan panas bumi merupakan solusi yang tepat untuk mengatasi permasalahan yang ada. Selain ramah lingkungan, potensi energi terbarukan sangat besar terutama energi matahari karena Indonesia terletak pada daerah khatulistiwa.

Pemanfaatan energi terbarukan ini telah banyak digunakan sebagai salah satu upaya untuk mengatassi ketergantungan terhadap bahan bakar fosil. Selain membutuhkan biaya yang besar, penggunaan bahan bakar fosil juga memiliki dampak negatif terhadap lingkungan [1][2][3]. Diantara sumber energi terbarukan yang sudah banyak diaplikasikan adalah energi dari matahari, hal ini dikarenakan energi matahari tersedia secara gratis dan melimpah. Energi matahari dikonversi menjadi energi listrik atau energi panas menggunakan perangkat sel surya. Energi listrik yang dihasilkan dari sel surya berbentuk energi searah atau DC sedangkan beban listrik yang tersedia banyak menggunakan sumber bolak balik atau AC. Untuk mengubah energi listrik DC menjadi energi
Listrik AC digunakan perangkat semikonduktor yang disebut dengan inverter [4][5]. Pada sistem pembangkit energi listrik menggunakan energi terbarukan, inverter merupakan komponen utama untuk mengubah tegangan searah atau DC menjadi tegangan bolak balik atau AC.

Inverter banyak dipakai dalam sistem tenaga listrik, peralatan rumah tangga, transportasi, industri, kedirgantaraan dan bidang lainya [6][7]. Bentuk gelombang keluaran dari inverter idealnya adalah sinusoidal namun kenyataan yang ditemukan tidak dan masih mengandung harmonik [8]. Akibat dari harmonik terutama arus keluaran dari inverter dapat menyebabkan kerusakan pada peralatan elektronik, overheating pada motor induksi akibat terjadinya osilasi, voltage droop, kesalahan pada pengukuran besaran listrik dan bisa mengakibatkan penyusutan umur atau life time dari peralatan listrik [5]. Oleh karena itu, harmonik harus direduksi sampai batas yang diizinkan. Menurut satndar IEEE 5192014 , voltage distortion limits untuk tegangan $\leqslant 1 \mathrm{kV}$ adalah $8 \%$ dan $5 \%$ untuk tegangan $>1 \mathrm{kV}$ dan $\leqslant 69 \mathrm{kV}[9]$.

Salah satu cara yang dapat dilakukan untuk mengurangi harmonik pada inverter adalah dengan menggunakan teknik Pulse Width Modulation (PWM) [10]. Beberapa mode modulasi pulsa yang banyak diterapkan diantaranya sinusoidal PWM (SPWM), space vector PWM (SVPWM), dan third harmonic pulse width modulation (THPWM) [11]. Tulisan ini lebih memfokuskan kepada penggunaan teknik SPWM dan filter pasif LC jenis low pass dalam upaya mengurangi nilai harmonik gelombang keluaran pada inverter tiga fasa. Penggunaan metode SPWM digunakan untuk mereduksi nilai harmonik pada gelombang arus sedangkan untuk mereduksi harmonik pada gelombang tegangan digunakanlah filter pasif.

\section{KAJIAN TEORI}

\section{A. Inverter Tiga Fasa}

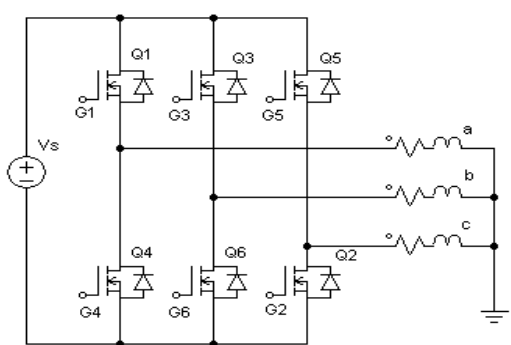

Gambar 1. Inverter Tiga Fasa 
Inverter tiga fasa terdiri dari 6 komponen switching dan membutuhkan 6 sinyal PWM untuk beroperasi (gambar 1). Inverter tiga fasa tersedia dalam beberapa pilihan topologi sesuai dengan kebutuhan, diantaranya Voltage Source Inverter (VSI) dan Current Source Inverter (CSI). Pada tulisan ini, inverter yang dipakai adalah inverter jenis VSI. Inverter jenis ini banyak digunakan di industri untuk sumber tegangan dengan fasa dan frekuensi dapat diatur [12].

\section{B. Distorsi Harmonik}

Salah satu penyebab terjadinya distorsi gelombang adalah akibat pemakain beban non linear pada sistem kelistrikan. Inverter adalah salah satu beban non linear yang banyak dipakai pada sistem kelistrikan dan ikut menyumbang terjadinya distorsi gelombang. Total harmonik distortion (THD) adalah istilah yang dipakai untuk menghitung nilai efektif dari komponen harmonik. Persamaan (1) digunakan untuk menghitung nilai THD tegangan keluaran inverter dan untuk menghitung nilai THD arus keluaran inverter dapat gunakan (2).

$$
\begin{aligned}
& T H D_{V}=\frac{\sqrt{\sum_{h>1}^{h_{\max }} V_{h}^{2}}}{V_{1}} \\
& T H D_{i}=\frac{\sqrt{\sum_{h>1}^{h_{\max } I_{h}^{2}}}}{I_{1}}
\end{aligned}
$$

Dimana $\mathrm{h}$ adalah orde harmonik

$\mathrm{V}_{\mathrm{h}}$ adalah harmonik tegangan

$\mathrm{V}_{1}$ adalah tegangan fundamental

$\mathrm{I}_{\mathrm{h}}$ adalah harmonik arus

$\mathrm{I}_{1}$ adalah arus fundamental

Analisis THD diperlukan untuk melihat kualitas tegangan dan arus keluaran pada inverter. Karena komponen harmonik menyebabkan gelombang keluaran tidak sinusoidal.

\section{Sinusoidal Pulse Width Mudulation (SPWM)}

Sinyal keluaran inverter dapat dikontrol menggunakan teknik PWM dengan mengatur periode $O N$ dan $O F F$ dari switching inverter. Diantara teknik PWM, mode SPWM lebih banyak digunakan karena untuk mengontrol tegangan dan frekuensi keluaran inverter dapat dilakukan sesuai dengan fungsi sinus yang digunakan [12]. Sinyal untuk pemicu pada switching inverter didapatkan dari komparasi sinyal segitiga yang juga disebut dengan sinyal carrier dengan sinyal sinusoidal tiga fasa yang juga disebut dengan sinyal reference. Sinyal carrier memiliki frekuensi jauh lebih tinggi dibandingkan dengan sinyal reference. Komparasi antara sinyal reference dan sinyal carrier dapat dilihat pada gambar 2. Perbandingan antara amplitudo sinyal reference dengan sinyal carrier dinamakan dengan index modulasi [11][12].

$$
M=\frac{A_{r}}{A_{c}}
$$

Dimana $\mathrm{M}$ adalah index modulasi dari sinyal SPWM

$$
A_{r} \text { adalah amplitudo sinyal reference }
$$

$A_{c}$ adalah amplitudo sinyal carrier

Index modulasi dari SPWM biasanya berada antara 0 dan 1. Semakin mendekati 1 maka nilai THD akan semakin berkurang. Berikut beberapa keuntungan menggunakan teknik SPWM untuk inverter tiga fasa mode VSI [13].

1. Metode SPWM mudah untuk diimplementasikan dan dikontrol
2. Variasi suhu tidak signifikan sehingga tidak terjadi degradasi dan pengurangan susut umur.

3. Susut daya berkurang terutama akibat pensaklaran rendah

4. Bisa diaplikasikan menggunakan mikroprosesor

5. Pemanfaatan sumber dc lebih efektif karena dapat menghasilkan nilai keluaran yang lebih tinggi

6. Dapat mereduksi harmonik orde rendah

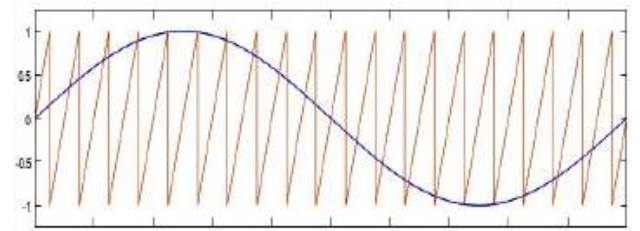

(a)

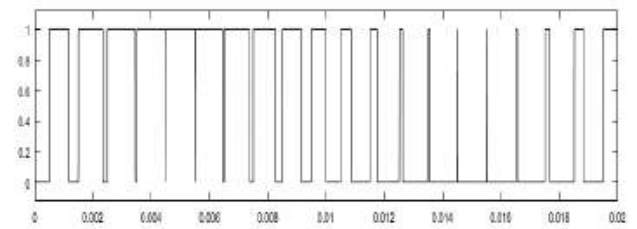

(b)

Gambar 2. Sinyal SPWM, (a) Komparasi Sinyal Sinusoidal dengan Segitiga, (b) Sinyal Switching.

\section{LC Low Pass Filter}

Mengurangi nilai harmonik yang dihasilkan oleh beban non linear seperti inverter dapat dilakukan dengan menggunakan nilai induktansi yang lebih besar tetapi untuk nilai daya besar membutuhkan biaya lebih. Selain itu, juga akan membuat respon dinamis sistem menjadi lebih buruk. Filter LC adalah induktor yang terpasang seri dengan inverter dan kapasitor dipasang secara paralel. Filter LC pada tulisan ini digunakan untuk mereduksi harmonik pada frekuensi tinggi. Kemampuan induktor yang digunakan harus lebih besar atau sama dengan nilai maksimum arus keluaran inverter. Sedangkan nilai induktansi sebaiknya lebih kecil agar riak keluaran inverter lebih kecil, losses

berkurang serta lebih ekonomis [14]. Gambar 3 adalah bentuk rangkaian filter LC jenis low pass filter.

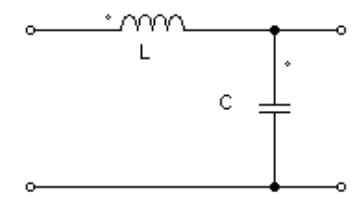

Gambar 3. LC Low Pass Filter

Persamaan (4) dapat digunakan untuk menentukan nilai frekuensi cut off dari filter LC [15].

$$
\begin{aligned}
f_{C} & =\frac{1}{2 \pi} \frac{1}{\sqrt{L C}} \\
X_{L} & =2 \pi f l \\
X_{C} & =\frac{1}{2 \pi f C} \\
Z & =\sqrt{\frac{L}{C}}
\end{aligned}
$$

Dimana $f_{C}$ adalah frekuensi cut off filter LC

$X_{L}$ adalah reaktansi induktif 
$X_{C}$ adalah reaktansi kapasitor

$\mathrm{Z}$ adalah impedansi

$\mathrm{L}$ adalah inductor

$\mathrm{C}$ adalah kapasitor

$f$ adalah frekuensi

Menentukan nilai rektansi induktor dapat digunakan (5), reaktansi kapasitor digunakan (6) dan menentukan karakteristik impedansi dari filter digunakan (7).

\section{HASIL DAN PEMBAHASAN}

Simulasi inverter tiga fasa seperti pada gambar 4 menggunakan parameter sebagai berikut.

1. Frekuensi switching $5 \mathrm{KHz}$

2. Frekuensi sistem $50 \mathrm{~Hz}$

3. Nilai beban $\mathrm{R} 20 \mathrm{Ohm}$

4. Nilai beban L $100 \mathrm{mH}$

5. Tegangan sumber inverter 380 Volt

6. Index modulasi 1

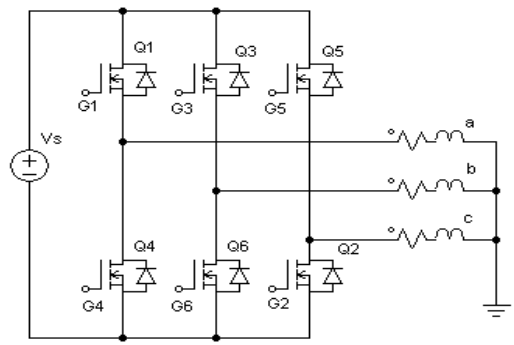

Gambar 4. Inverter Tiga Fasa Sebelum Difilter

Gambar 5 dan 6 adalah bentuk gelombang keluaran inverter tiga fasa menggunakan metode SPWM. Gelombang keluaran inverter belum berbentuk sinusoidal namun sudah membentuk pola sinus meskipun masih terdistorsi.
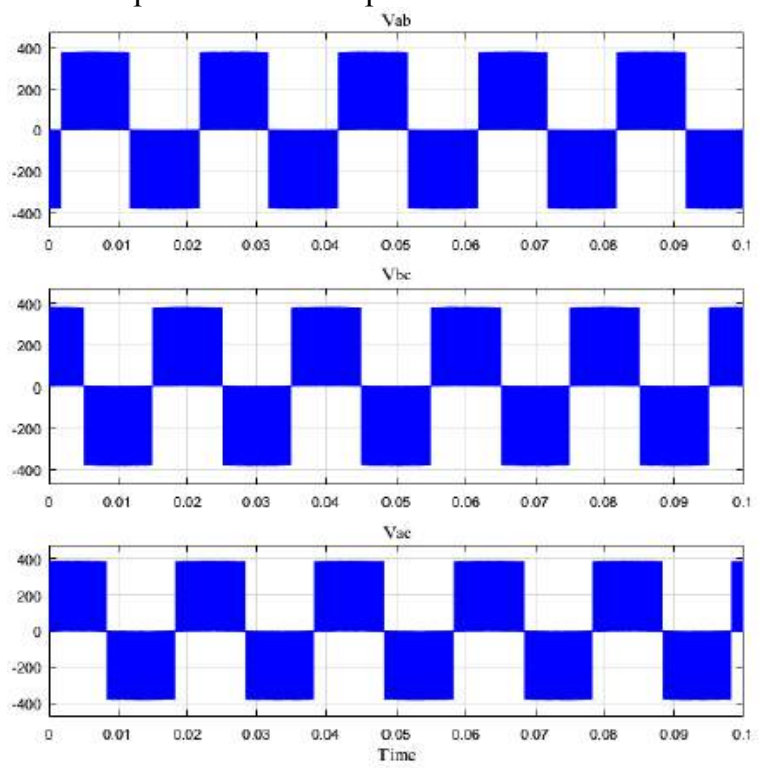

Gambar 5. Tegangan Fasa Keluaran Inverter Sebelum Dipasang Filter $\mathrm{LC}$
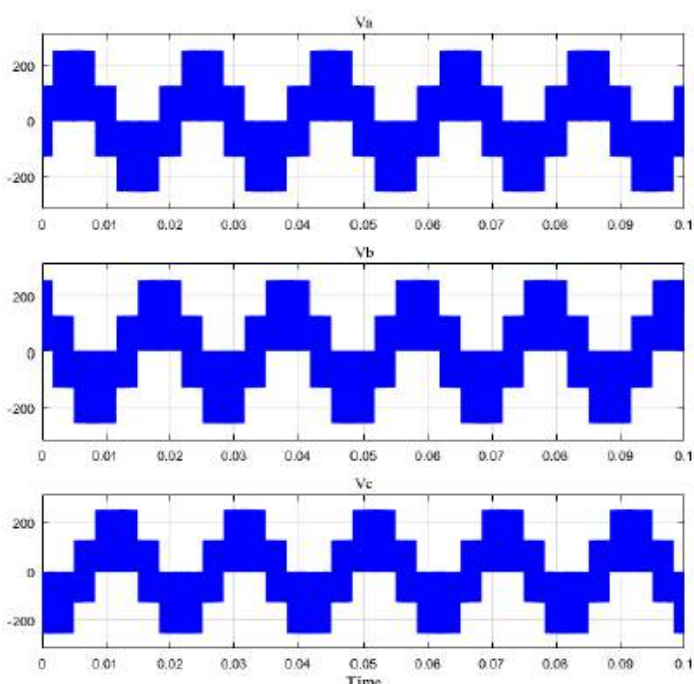

Gambar 6. Tegangan Fasa-Fasa Keluaran Inverter Sebelum Dipasang Filter LC

Sedangkan gambar 7 adalah gelombang arus keluaran inverter yang sudah berbentuk sinusoidal.
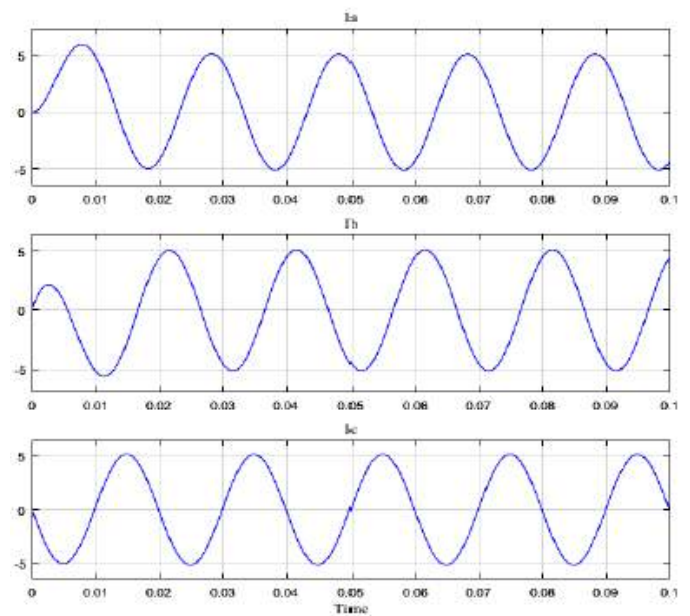

Gambar 7. Arus Keluaran Inverter Sebelum Dipasang Filter LC

Gambar 8, 9 dan 10 adalah grafik spektrum harmonik dengan frekuensi fundamental $50 \mathrm{~Hz}$ menggunakan metode SPWM. Gambar 8 dan 9 merupakan spektrum harmonik tegangan fasa dan tegangan fasa-fasa keluaran inverter yang masih mengandung harmonik sebesar $68,72 \%$ dan $68,71 \%$.

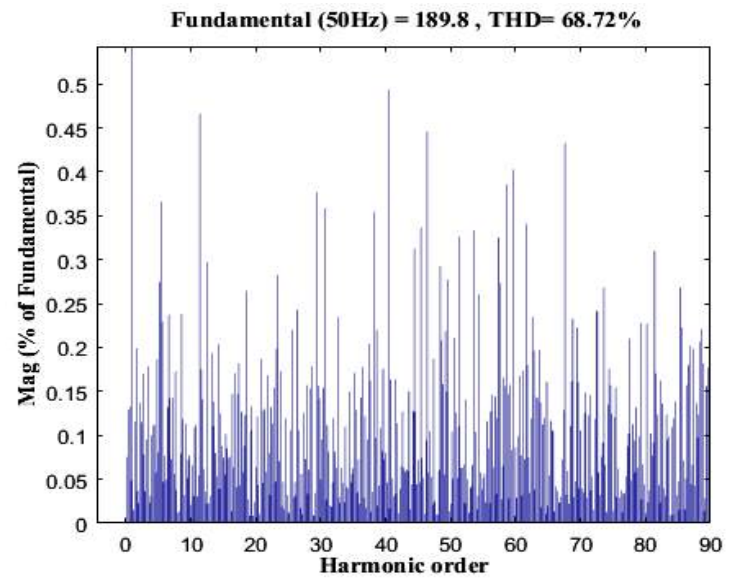

Gambar 8. Spektrum Harmonik Tegangan Fasa Keluaran Inverter Sebelum Dipasang Filter LC 


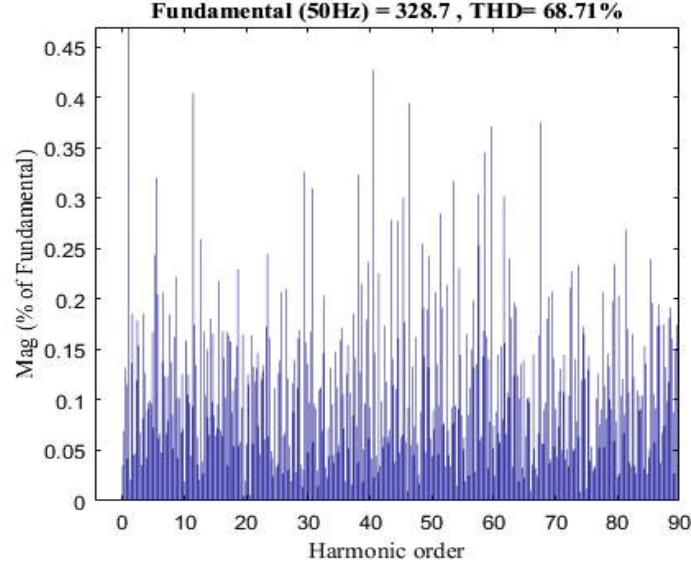

Gambar 9. Spektrum Harmonik Tegangan Fasa-Fasa Keluaran Inverter Sebelum Dipasang Filter LC

Gambar 10 merupakan spektrum harmonik arus dengan nilai $0,92 \%$, nilai ini masih berada dalam batas yang diizinkan.

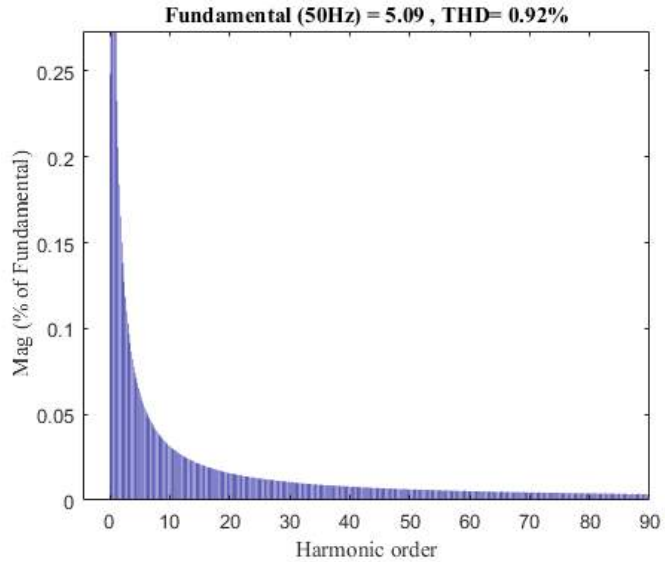

Gambar 10. Spektrum Harmonik Arus Keluaran Inverter Sebelum Dipasang Filter LC

Salah satu cara yang dilakukan untuk mereduksi nilai harmonik pada tegangan keluaran inverter tiga fasa adalah dengan menggunakan filter pasif jenis low pass. Persamaan (5), (6) dan (7), digunakan untuk menghitung nilai nilai filter untuk $\mathrm{L}=89 \mathrm{mH}$ dan untuk $\mathrm{C}=95 \mu \mathrm{F}$.

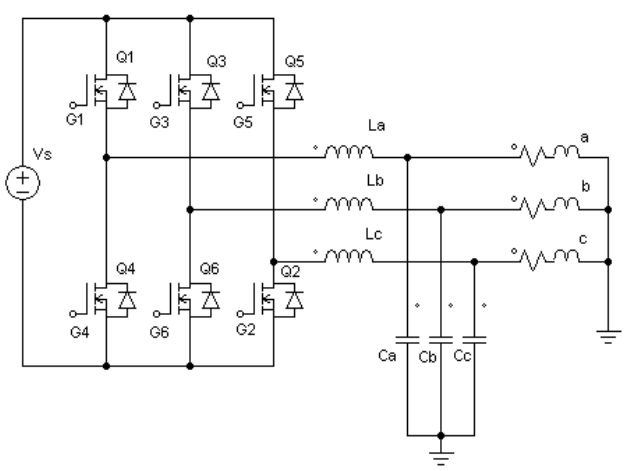

Gambar 11. Inverter Tiga Fasa Menggunakan Filter LC

Gambar 12, 13 dan 14, masing-masing adalah gambar gelombang tegangan fasa, tegangan fasa-fasa dan gelombang arus keluaran inverter tiga fasa. Masing-masing gelombang tersebut sudah berbentuk sinusoidal.
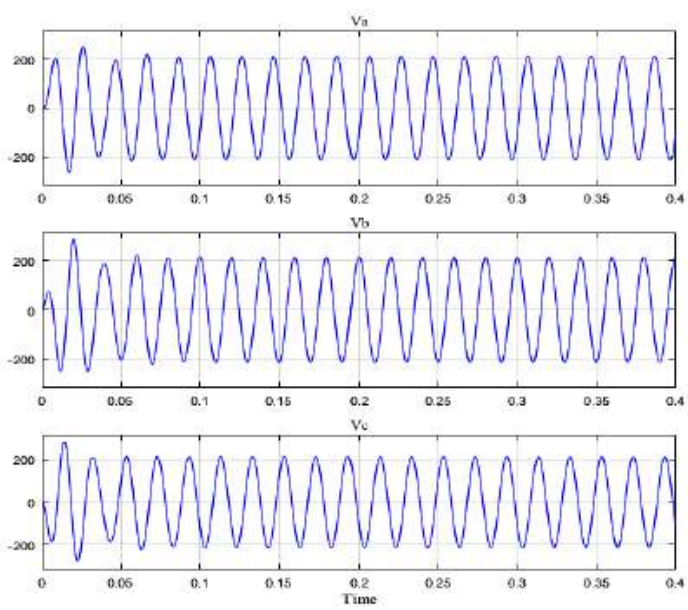

Gambar 12. Gelombang Tegangan Fasa Keluaran Inverter Setelah Dipasang Filter LC
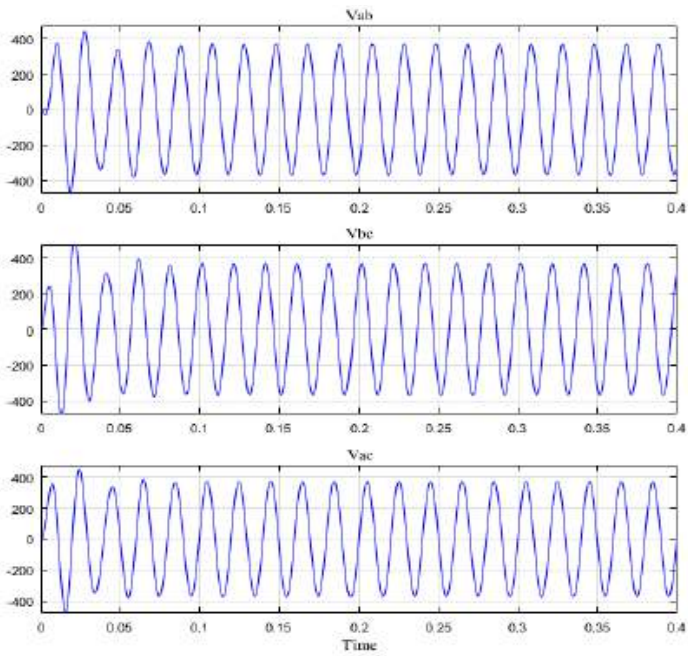

Gambar 13. Gelombang Tegangan Fasa-Fasa Keluaran Inverter Setelah Dipasang Filter LC
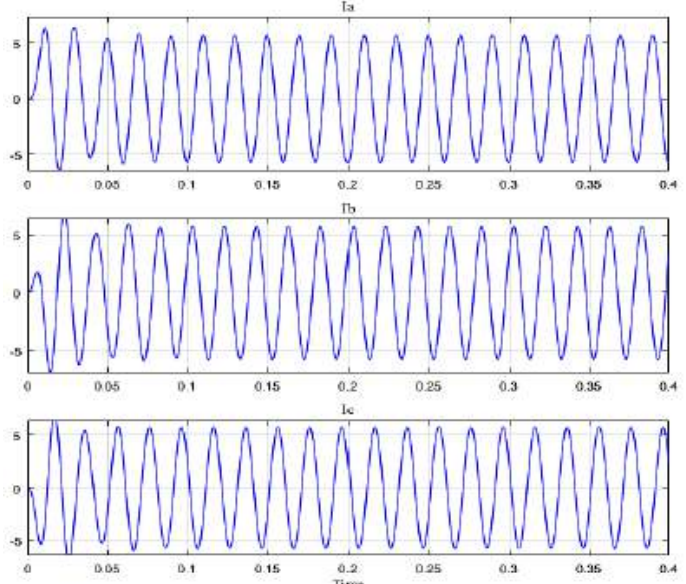

Gambar 14. Gelombang Arus Keluaran Inverter Setelah Dipasang Filter LC

Gambar 15 dan 16 adalah spektrum harmonik tegangan fasa dan tegangan fasa-fasa keluaran inverter. Setelah menggunakan filter pasif LC jenis low pass maka terdapat pengurangan nilai harmonik. Harmonik tegangan fasa berkurang dari $68,72 \%$ menjadi $0,21 \%$, sedangkan tegangan fasa-fasa berkurang dari $68,71 \%$ menjadi $0,25 \%$. Nilai tersebut sudah memenuhi batas yang diizinkan sesuai dengan standar IEEE 519-2014. 


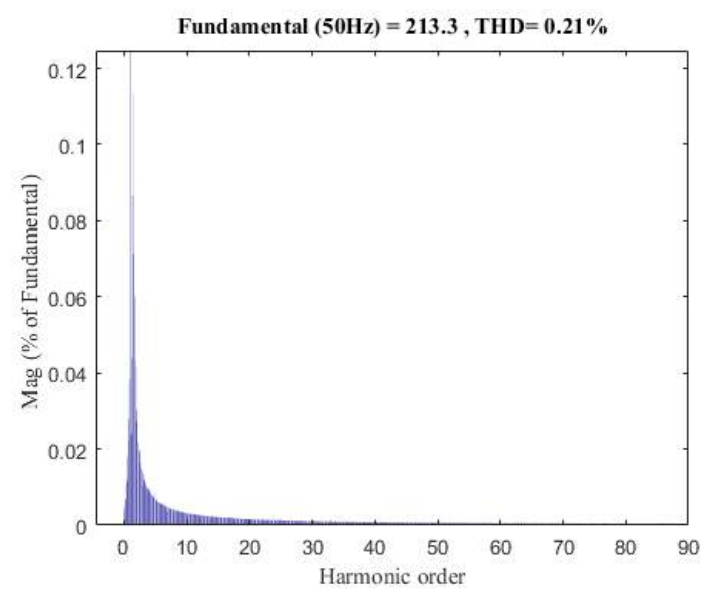

Gambar 15. Spektrum Harmonik Tegangan Fasa Keluaran Inverter Setelah Dipasang Filter LC

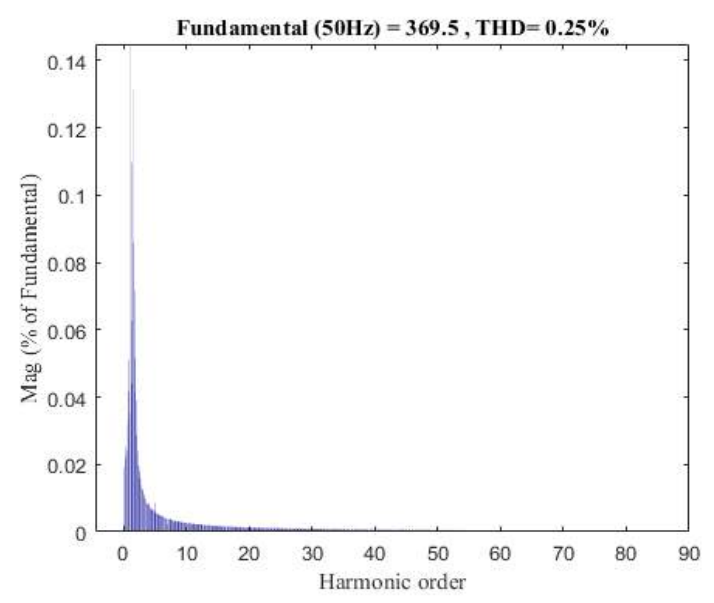

Gambar 16. Spektrum Harmonik Tegangan Fasa-Fasa Keluaran Inverter Setelah Dipasang Filter LC

Gambar 15 dan 16 adalah spektrum harmonik tegangan fasa dan tegangan fasa-fasa keluaran inverter. Setelah menggunakan filter pasif LC jenis low pass maka terdapat pengurangan nilai harmonik. Harmonik tegangan fasa berkurang dari $68,72 \%$ menjadi $0,21 \%$, sedangkan tegangan fasa-fasa berkurang dari $68,71 \%$ menjadi $0,25 \%$. Nilai tersebut sudah memenuhi batas yang diizinkan sesuai dengan standar IEEE 519-2014.

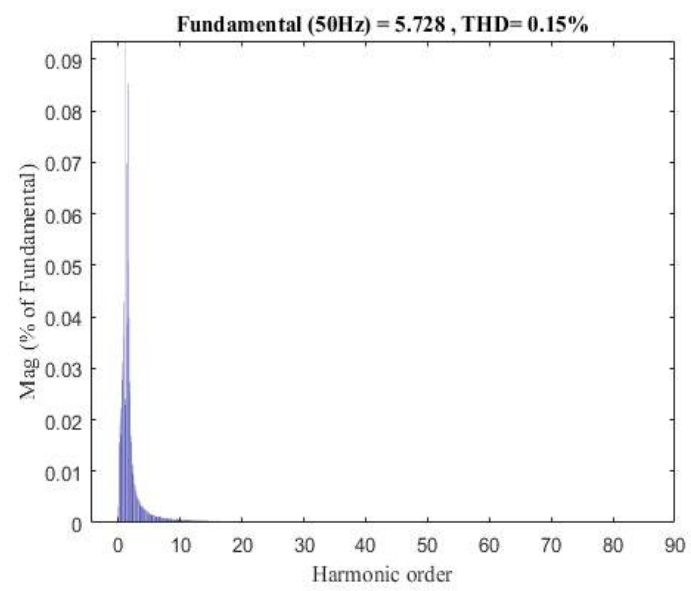

Gambar 17. Spektrum Harmonik Arus Keluaran Inverter Setelah Dipasang Filter LC

Setelah dipasang filter LC, nilai harmonik arus juga mengalami pengurangan yaitu dari $0,92 \%$ menjadi $0,15 \%$ dan nilai ini juga sudah sesuai dengan standar yang berlaku.

\section{KESIMPULAN}

Dari simulasi yang dilakukan dapat disimpulkan bahwa metode SPWM dapat meningkatkan kualitas keluaran inverter. Nilai THD arus jauh dibawah batas yang diizinkan sesuai standar IEEE 519-2014. Penggunaan filter pasif LC dapat memperbaiki gelombang tegangan keluaran inverter. Sehingga setelah pemasangan filter LC, nilai THD gelombang keluaran berkurang secara signifikan. Setelah pemakaian filter LC, nilai THD tegangan fasa berkurang sebesar $68,51 \%$, nilai THD tegangan fasa-fasa berkurang sebesar $68,46 \%$. Nilai THD arus keluaran berkurang sebesar $0,77 \%$, hal ini disebabkan karena nilai THD arus yang sudah rendah pada waktu menggunakan metode SPWM.

\section{REFFERENSI}

[1] Krismadinata, Asnil, I. Husnaini, and H. Hendri, "Microcontroller based multilevel inverter for photovoltaic system," Adv. Sci. Lett., vol. 23, pp. 3859-3863, 2017.

[2] Krismadinata, Asnil, I. Husnaini, and E. Astrit, "Microcontroller based 120 and 180 conduction modes of three-phase inverter for photovoltaic generation," ARPN J. Eng. Appl. Sci., vol. 13, no. 11, pp. 3579-3586, 2018.

[3] N. I. Raju, S. Islam, and A. A. Uddin, "Sinusoidal PWM signal generation technique for three phase voltage source inverter with analog circuit \& simulation of PWM inverter for standalone load \& micro-grid system," Int. J. Renew. Energy Res., vol. 3, no. 3, pp. 647-658, 2013.

[4] S. Maheshri and P. Khampariya, "Simulation of single phase SPWM ( Unipolar ) inverter," Int. J. Innov. Res. Adv. Eng., vol. 1, no. 9, pp. 1218, 2014.

[5] Asnil, Krismadinata, and I. Husnaini, "Inverter tiga fasa untuk pembangkit listrik tenaga surya," Pros. Semin. Nas. Tek. Elektro (FORTEI 2017), pp. 163-166.

[6] J. Song, X. Zhang, L. Zheng, Y. Gao, and Y. Song, "Simulation and experiment of three-phase voltage SPWM inverter," Proc. 2015 10th IEEE Conf. Ind. Electron. Appl. ICIEA 2015, pp. 1324-1329, 2015.

[7] N. I. Raju, M. S. Islam, T. Ali, and S. A. Karim, "Study of SPWM technique \& simulation of designed analog circuit (Op-Amp) controlled three phase PWM inverter with harmonic reduction," 2013 Int. Conf. Informatics, Electron. Vision, ICIEV 2013, pp. 4-9, 2013.

[8] M. A. Ghalib and Y. S. Abdalla, "Design and implementation of a pure sine wave single phase inverter for photovoltaic applications," $2014 \mathrm{Zo.}$ 1 Conf. Am. Soc. Eng. Educ., pp. 1-8, 2014.

[9] C. Studies, "IEEE Standard 519-2014," 2014.

[10] K. V. Kumar, P. A. Michael, J. P. John, and S. S. Kumar, "Simulation and comparison of SPWM and SVPWM control for three phase inverter," ARPN J. Eng. Appl. Sci., vol. 5, no. 7, pp. 61-74, 2010.

[11] M. Esa, M. Abdul, and M. Nawaz, "THD analysis of SPWM \& THPWM controlled three phase voltage source inverter," Int. Res. J. Eng. Technol., vol. 4, no. 10, pp. 391-398, 2017.

[12] T. Bhattacharjee, "Design of SPWM based three phase inverter model," 2018 Technol. Smart-City Energy Secur. Power, pp. 1-6, 2018.

[13] R. Zahira, "SPWM technique for reducing harmonics in three-phase nonlinear load," IEEE 2nd Int. Conf. Electr. Energy Syst., pp. 56-60, 2014.

[14] M. Hojabri and M. Hojabri, "Design, application and comparisonof passive filter for three-phase grid-connected renewable energy systems," ARPN J. Eng. Appl. Sci., vol. 10, no. 22, pp. 10691-10697, 2015.

[15] K. H. Ahmed, S. J. Finney, and B. W. Williams, "Passive filter design for three-phase inverter interfacing in distributed generation," 2007. 